\section{Retention System and Splinting on Morse Taper Implants in the Posterior Maxilla by 3D Finite Element Analysis}

Cleidiel Aparecido Araujo Lemos ${ }^{1}$, Fellippo Ramos Verri ${ }^{1}$, Joel Ferreira Santiago Júnior ${ }^{2}$, Daniel Augusto de Faria Almeida ${ }^{3}$, Victor Eduardo de Souza Batista ${ }^{1}$, Pedro Yoshito Noritomi ${ }^{4}$, Eduardo Piza Pellizzer ${ }^{1}$
'Department of Dental Materials and Prosthodontics, Araçatuba Dental School, UNESP - Universidade Estadual Paulista, Araçatuba, SP, Brazil ${ }^{2}$ Department of Health Sciences, University of Sacred Heart, USC - Universidade do Sagrado Coração, Bauru, SP, Brazil ${ }^{3}$ Department of Restorative Dentistry, UNIFAL - Universidade Federal de Alfenas, Alfenas, MG, Brazil ${ }^{4}$ Renato Archer Information Technology Center, Campinas, SP, Brazil.

Correspondence: Prof. Eduardo Piza Pellizzer, Rua José Bonifácio, 1193, 16015-050 Araçatuba, SP, Brasil. Tel: +55 18-3636-3297. e-mail: ed.pl@uol.com.br

\section{Introduction}

Rehabilitation with implant-supported fixed prostheses is a predictable modality to restore lost function and esthetics in partially or totally edentulous patients. Treatment longevity depends on the preservation of bone around the implant. Morse taper (MT) implants have shown high success rates with good bone preservation in implantsupported restorations (1). This clinical performance can be explained by the reduced incidence of microgap and bacterial contamination (2). Furthermore, compared to other connections, the MT connection permits superior bone crest stability under axial and lateral loads (3).

The make decision about the use or not of splinted crowns is based on different factors such as: implant length, occlusion, hygiene, connection type and difficulty achieving a passively fitting framework (4). The maxillary posterior area after tooth loss often can limits the use of the longer implants. In these situations, short implants may be recommended with the aim of avoiding auxiliary surgical procedures (5). However, short implants may present greater risks when compared to implants with conventional lengths, especially when placed in the posterior region (6). Thus, the splinted crowns of short implants can be indicated in atrophic maxilla because transmit more uniform stress in structures with higher reduction of stress in the periimplant region (4).

Different retention systems, such as screw- or cementretained systems, are available for implant-supported restorations. The retention system is chosen on the basis of the advantages and disadvantages of each system, as well as the clinician's preference or clinical experience (7). Screw-retained prostheses have advantage of reversibility allowing maintenance mainly in multiple prostheses, predictable retention, lower biological risks, but it presents an unfavorable aesthetic, more difficulty in achieving stable occlusal contacts, as well as greater risks of mechanical complications. Cement-retained prosthesis has as main characteristic aesthetics, flexibility to correct implant position, occlusal table integrates, more likely to achieve passive fit, and ease fabricate and cost; however, there is no predictability regarding reversibility, show greater biological risks due to excess cement, need for a minimum of inter occlusal space for the abutment to allow retention of the crown (8). However, there is currently no consensus about the use of splinting or the best type of retention system for 
fixed implant-supported restorations with MT connections.

The aim of this study was to evaluate the influence of splinting and different retention systems in the MT connection. The null hypotheses were as follows: (1) there would be no difference in stress distribution between cement- and screw-retained implant-supported fixed restorations; and (2) there would be no difference in stress distribution between single-unit and splinted prostheses.

\section{Materials and Methods}

\section{Experimental Design}

This research was designed to consider three variation factors: the retention system (screw- or cement-retained), crown design (non-splinted or splinted) and loading condition (axial and oblique). Four models were created to test these factors (Table 1).

\section{D Finite Element Modeling}

The 3D finite element analysis (FEA) methodology used here follows that of previous studies $(3,9)$. Each model was composed of a bone block of the maxillary area of the first premolar to first molar, with trabecular bone in the center surrounded by $1 \mathrm{~mm}$ of cortical bone. Information for the bone block was obtained by computerized tomography (sagittal section) of the region. Modeling was performed with InVesalius software (CTI Renato Archer, Campinas, $\mathrm{SP}$, Brazil) and surface simplification with Rhinoceros 4.0 software (NURBS Modeling for Windows, Seattle, WA, USA).

The implant design was a simplified version of the original 1-connection MT design (Morse taper - Torq, Conexão Sistemas de Prótese Ltda, Aruja, SP, Brazil). The MT implant measured $4 \mathrm{~mm}$ in diameter and $10,8.5$, and $7 \mathrm{~mm}$ in length for the first premolar, second premolar and first molar, respectively. A prosthetic UCLA-indexed abutment of $\mathrm{Co}-\mathrm{Cr}$ was used for both retention systems. MT implants were simulated with 1-mm subcrestal placement.

The crown design was obtained from an artificial mandibular molar tooth (Odontofix Indústria e Comércio de Material Odontológico Ltda., Ribeirão Preto, SP, Brazil)

Table 1. Specifications of the models of Morse taper connection implants with lengths of $10 \mathrm{~mm}$ (1st premolar), $8.5 \mathrm{~mm}$ (2nd premolar) and $7 \mathrm{~mm}$ (1st molar).

\begin{tabular}{|c|c|c|c|}
\hline Models & $\begin{array}{c}\text { Fixation } \\
\text { system }\end{array}$ & Crowns & Nodes/Elements \\
\hline Model 1 (M1) & \multirow{2}{*}{$\begin{array}{l}\text { Screw- } \\
\text { retained }\end{array}$} & Single-unit & $2125693 / 758893$ \\
\hline Model 2 (M2) & & Splinted & 2169216/787377 \\
\hline Model 3 (M3) & \multirow{2}{*}{$\begin{array}{l}\text { Cement- } \\
\text { retained }\end{array}$} & Single-unit & $1886171 / 983572$ \\
\hline Model 4 (M4) & & Splinted & $1904817 / 996376$ \\
\hline
\end{tabular}

and digitized by using a 3D scanner (MDX-20; Roland DG, São Paulo SP, Brazil). Images were exported to Rhinoceros 4.0 CAD software for modeling. Occlusal surface details were added with the SolidWorks CAD software package (SolidWorks Corp, Waltham, MA, USA). Implant-supported crowns were simulated with a screw or cement connection to the MT implant. The cement layer was $50-\mu m$-thick zinc phosphate cement. Crowns were designed as singleunit (non-splinted) or splinted crowns. All implant and abutment designs were simplified by using SolidWorks and Rhinoceros 4.0 software packages. Simplified designs maintained similarity to the real models (Fig. 1).

After modeling the solids, geometries were exported to FEA software for pre- and post-processing (FEMAP 11.2, Siemens PLM, Santa Ana, CA, USA), to obtain tetrahedral parabolic solid elements with 10 nodes used for mesh generation for all involved structures. Mechanical properties of each simulated material were attributed to the meshes by using literature values (10-12) (Table 2). All materials were assumed to be homogeneous, isotropic and linearly elastic.

\section{Interface, Boundary Conditions and Loadings}

All contacts were simulated as symmetric welds, except for the abutment/implant and single-unit crown contacts that were simulated by symmetric contacts. Axes ( $x$, $y$ and $z)$ were fixed in both bone block sections (cortical and trabecular). All other model surfaces were unrestricted. The non-linear applied axial force was $400 \mathrm{~N}(100 \mathrm{~N}$ for both premolars and $200 \mathrm{~N}$ for the first molar) at a point determined on the tip of each cusp. The non-linear oblique load was $200 \mathrm{~N}$ ( $50 \mathrm{~N}$ for both premolars and $100 \mathrm{~N}$ for first molar), suppressing the lingual cusps (Fig. 1).

\section{Criteria for Stress Analyses}

Models generated in FEMAP 11.2 were exported to the NeiNastran 11.0 software package (Noran Engineering, Inc., Westminster, CA, USA). After the analytical problems were

Table 2. Mechanical properties of the simulated materials

\begin{tabular}{lccc}
\hline Material & $\begin{array}{c}\text { Elastic } \\
\text { Modulous } \\
(\mathrm{GPa})\end{array}$ & $\begin{array}{c}\text { Poisson } \\
\text { ratio } \\
(\mathrm{v})\end{array}$ & References \\
\hline Trabecular bone tissue & 1.37 & 0.30 & {$[8]$} \\
Cortical bone tissue & 13.7 & 0.30 & {$[8]$} \\
Titanium (Implant) & 110.0 & 0.33 & {$[9]$} \\
Cr-Co Alloy (Abument) & 218.0 & 0.33 & {$[9]$} \\
Feldspathic Ceramic & 82.8 & 0.35 & {$[3]$} \\
Zinc phosphate cement & 22.4 & 0.35 & {$[10]$} \\
\hline
\end{tabular}


solved, the models were imported to the FEA software to plot maps of the stresses in units of mega-Pascal (MPa). Von Mises stress analysis was used for implant and prosthetic components (ductile materials). Maximum principal stress $\left(\sigma_{\max }\right)$ was used for bone tissue (friable materials), and are distinguished between tensile stresses (positive values) and compressive stresses (negative values) (3).

\section{Results}

Von Mises Stress Analysis of Implants/Abutments

Under axial loading, no differences in the stress distributions of implants/components were observed. Under oblique loading, greater stress concentration was observed compared to axial loading. Compared to screw-retained prostheses (M1, M2), cement-retained prostheses (M3, M4)
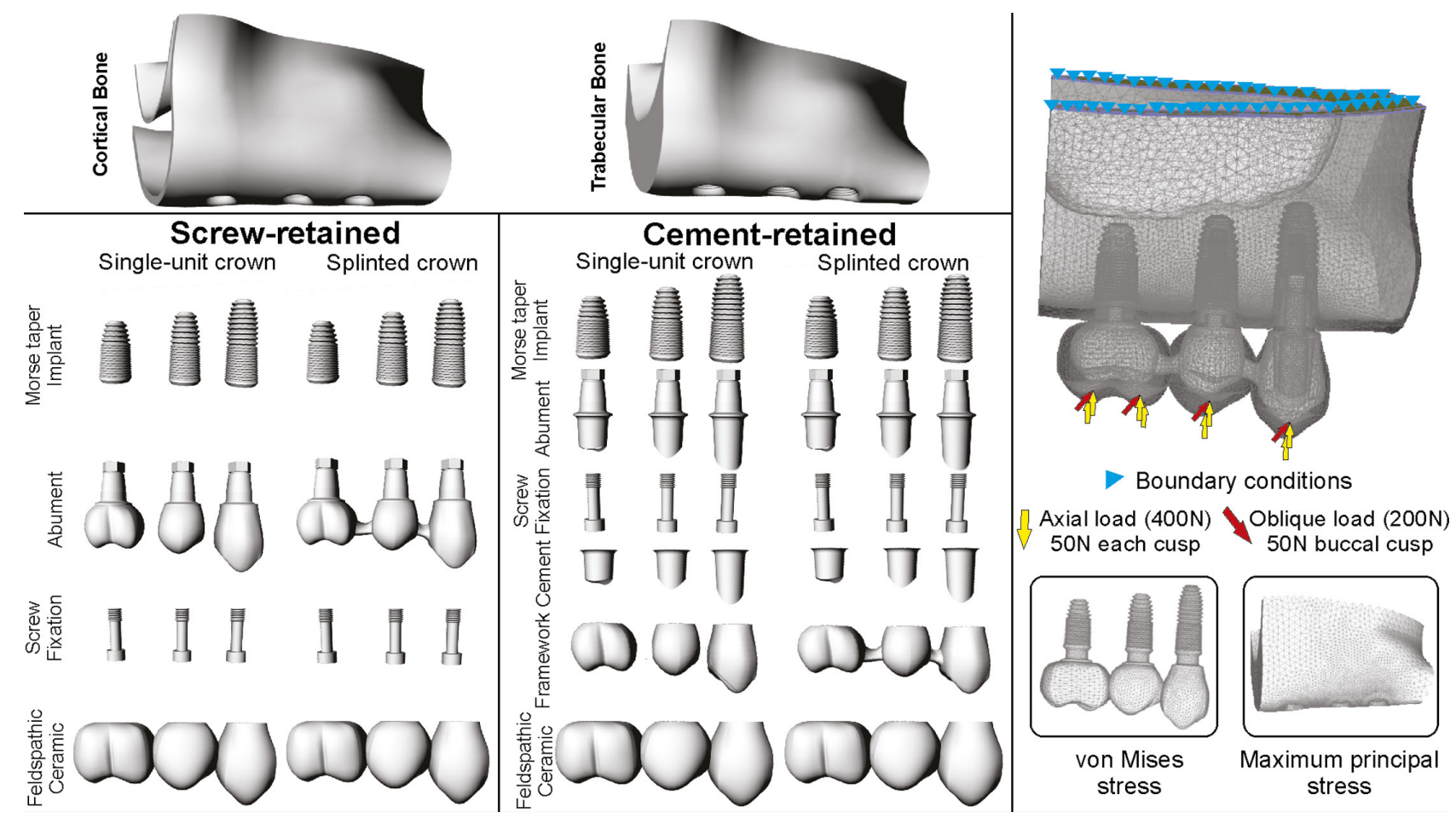

Figure 1. Schematic view of simulated solid and meshes of structures with analyzed structures, load conditions and restrictions.
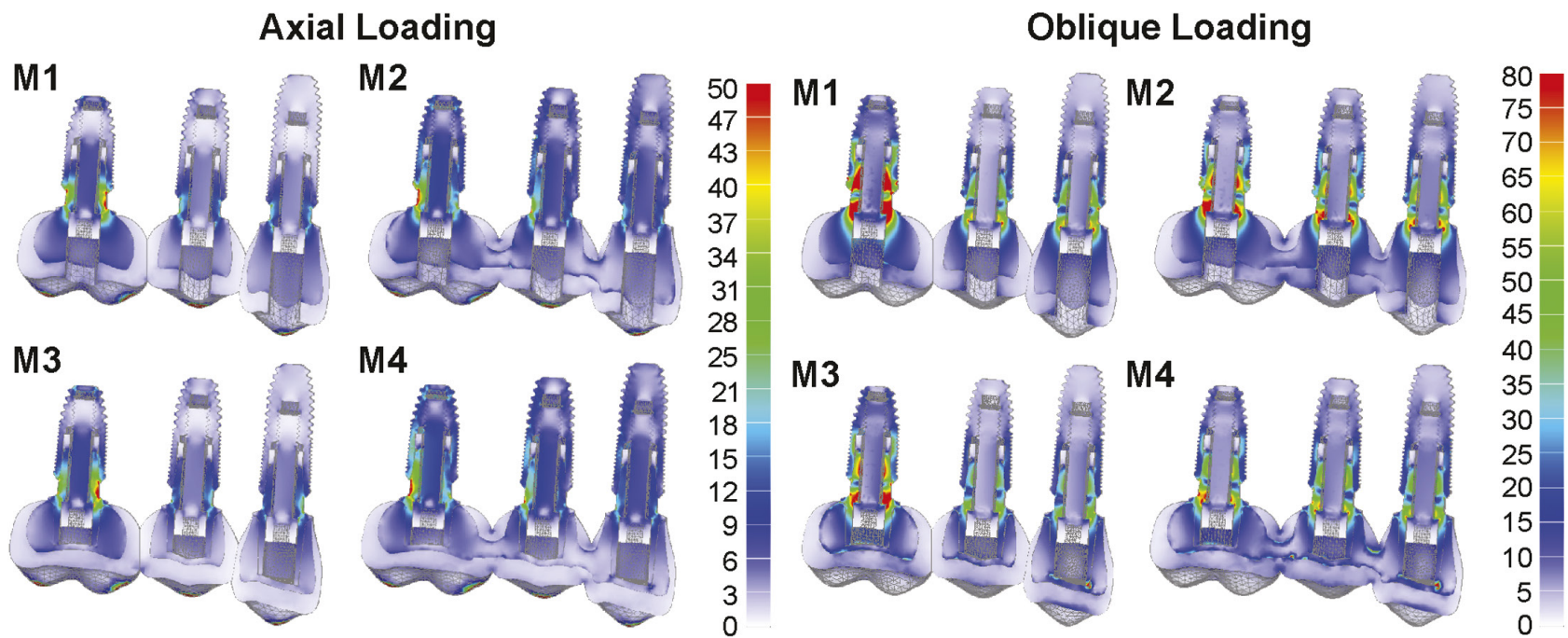

Figure 2. Von Mises maps to stress distribution on implant/components. 
showed better stress distribution in implants/components, regardless of the type of crown. Splinted crowns (M2, M4) favored stress distribution, especially in the first molar region (Fig. 2).

\section{Maximum Principal Stress Analysis of Bone Tissue}

Axial loading, similar levels of tensile and compressive stresses in cortical bone were obtained for the first and second premolars. The first molar showed higher tensile stress in all models, with greater concentration of stress for screw-retained prostheses (M1, M2) compared to cemented prostheses (M3, M4). No difference was found for the splinted crown design for both retention systems (Figs. 3 and 4). Under oblique loading, cemented prostheses (M3, M4) showed better stress distribution than screwed prostheses (M1, M2). The splinted crown was favorable to stress distribution only for the screwed prosthesis, with no difference for the cemented prosthesis (Figs. 3 and 4).

\section{Discussion}

MT implants present better biomechanical properties than other connections (3), favoring long-term bone preservation (1). The internal conical connection provides better dissipation of tension, due to the high stability of the MT connection (13). In this report, the first null hypothesis was rejected. Differences were found between retention systems, with cemented prostheses showing better stress distribution. These results corroborate those of other studies reporting the superiority of cemented systems compared to screwed prostheses $(14,15)$.

There are different theories to explain the better biomechanical behavior of cemented prostheses. For
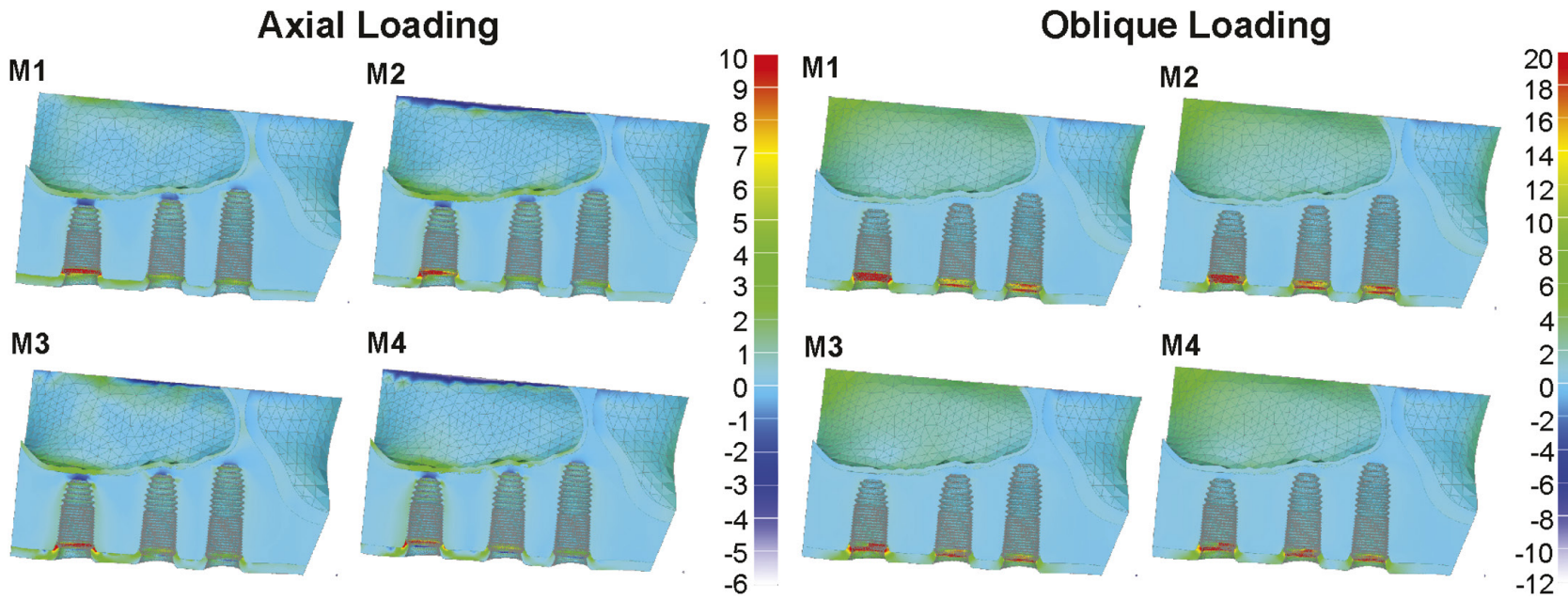

Figure 3. Maximum principal stress maps of distribution on cortical and trabecular bone tissue.

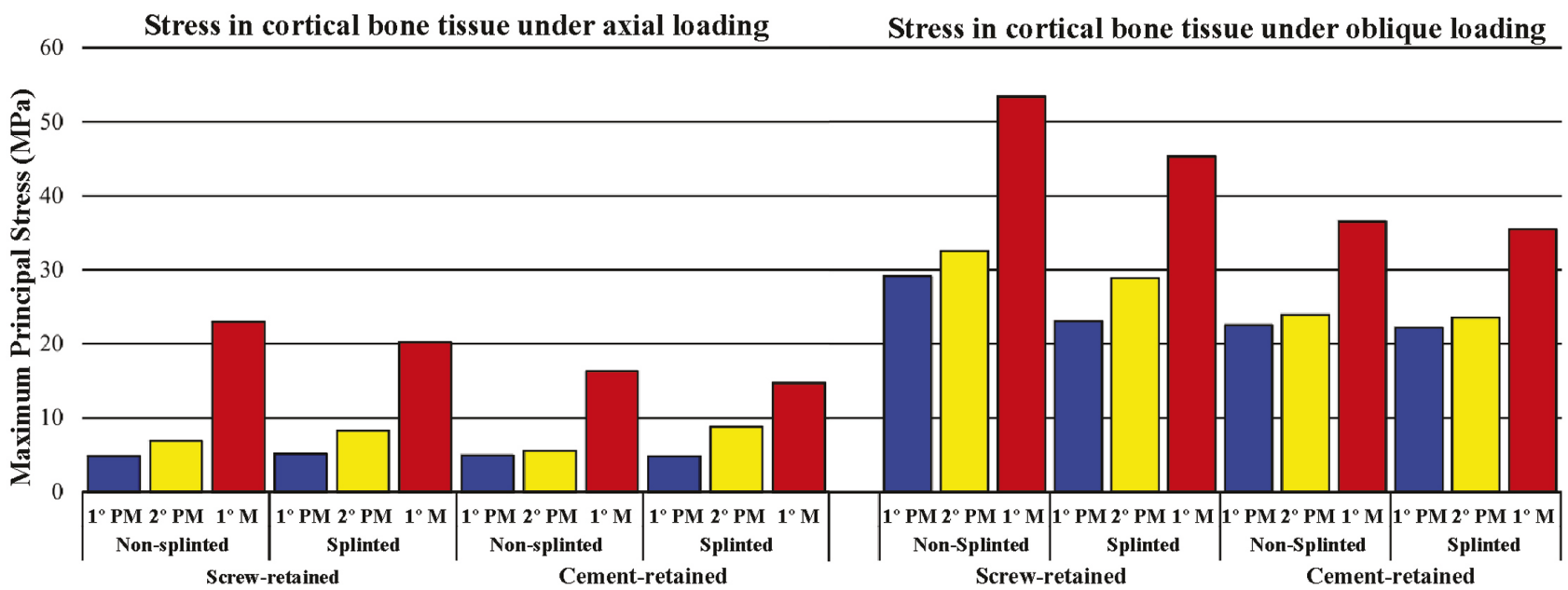

Figure 4. Stress values $(\mathrm{MPa})$ in maximum principal stress $\left(\sigma_{\max }\right)$ on cortical bone tissue under axial and oblique loading. 
example, it has been proposed that the screw access hole helps to transfer stress off the long axis of the implant, and that different restorative materials can transfer occlusal loads laterally to the implant instead of axially (7). The cement also may be better at filling discrepancies, absorbing and equalizing the stress of deformations caused by contact between the abutment and implant in the prosthesis structure (16). These factors can contribute to fixation screw of screwed prosthesis present stress overload in the structure, which contributes to greater complication rates can explain the frequent failures (e.g. screw loosening or fracture) that are observed in screwed prostheses $(7,15,17)$. The high risk in the screw-retained prosthesis can be related to lower preload in the screw with displacement (penetration and gaps) higher and concentrated on the threads of the screw/or abutment when compared to cement-retained (15). This difference can be even greater when use a one-piece abutment for cemented prostheses (3), since the type of abutment can influence biomechanical behavior (18). Thus, to eliminate the possibility of bias, the same abutment (UCLA casting in $\mathrm{Co}-\mathrm{Cr}$ ) was considered for both retention systems. The results of this study reinforce the notion that cemented the implants/components for the splinted crowns on both retention systems. In the bone tissue was observed difference for splinted compared to non-splinted crowns for the screwed prostheses under oblique loading. Similarly, other studies reported that splinting favors a reduction in stress in the implants/components and, consequently, bone tissue, especially for screwed prostheses under oblique loading $(19,20)$. Splinting favors the sharing of stress between implants, because a rigid structure acts to unite the crowns (20). The larger load in the molar area is due to a greater occlusal table over a short implant. Short implants are recommended for maxillary posterior region (molar) due to poor availability of bone tissue; however, short implants are more susceptible to failures rates than conventional implants (6). Thus, the splinting of short implants with implants of longer length is indicated in these situations (4). Splinted crowns help to distribute the stress between the splinted implants. In this study the increase in stress in implants placed in the premolar area after splinting prostheses is not harmful, since these implants show greater length, and the increased length of the implant favors to stress distribution on the bone tissue (21). So, the splinting of short implants with implants of longer length is indicated in these situations (20).

The difference in stress with splinting was observed only for the screwed prostheses. This finding is consistent with the study of Yilmaz et al. (22) which found no influence of splinting for cemented prostheses. Thus, in cases where a cemented prosthesis is used, a single-unit prosthesis should be preferred. This non-splinted crowns allows ease of access in the interproximal region, favoring patient hygiene (23) and adaptation to the prosthesis, with increased quality of life (24).

All of the models analyzed in this study showed periimplant areas of compressive and tensile stresses that were within physiological limits described in the literature of ultimate strength of cortical bone (7276 MPa for tensile stress, 140-170 MPa for compressive stress) (25). FEA is a useful tool for evaluating preclinical situations and determining the stress distribution in individualized structures $(3,9,11)$. One of the limitations present in this study was the use of symmetric contacts instead of frictional contacts for the analyzed structures, because this contact demanding on the computational capacity of highperformance in these complex models. Thus, the results from FEA studies permit a better understanding of biomechanical behavior; however, these inherent limitations of FEA must be kept in mind and should be carefully extrapolated to the clinic. Thus, when combined with well-designed clinical studies, the results in this paper could serve as a guideline for implant dentistry, but controlled clinical studies should be conducted to verify the biomechanical effects clinically. Within the limitations of this study, cemented prostheses on MT implants had more favorable stress distributions in the implants/components and bone tissue. However, splinting improved the stress distribution only in screwed prostheses on MT implants under oblique loading.

\section{Resumo}

0 objetivo deste estudo foi avaliar diferentes sistemas de retenção (cimentada $x$ parafusada) e configuração da coroas (unitárias $x$ esplintadas) de próteses fixas implantossuportadas em relação a distribuição de tensões nos implantes/componentes e tecido ósseo pela análise de elementos finitos 3D. Quatro modelos 3D foram simulados com auxilio dos programas Invesalius, e Rhinoceros 3D, e SolidWorks. Os modelos foram confeccionados simulando bloco ósseo de região posterior da maxila (tipo ósseo III), com 3 implantes cone Morse com $4,0 \mathrm{~mm}$ de diâmetro e diferentes comprimentos, suportando prótese metalocerâmica de 3 elementos. Os modelos foram processados pelos programas FEMAP e NEiNastran sob força axial de $400 \mathrm{~N}$ e obliqua de $200 N$. Os resultados foram plotados através de mapas de tensão de von Mises (vM) (implantes e componentes) e tensão máxima principal (TMP) (tecido ósseo). Sobre o carregamento axial, não foi observada diferenças entre os diferentes sistemas de retenção e tipo de prótese na distribuição das tensões nos implantes/componentes, porém, sobre o carregamento obliquo as próteses cimentadas apresentaram melhor distribuição de tensões em comparação com as próteses parafusadas, enquanto que as próteses esplintadas apresentou uma tendência de redução das tensões no implante do primeiro molar. No tecido ósseo as próteses cimentadas apresentaram melhor distribuição das tensões em comparação com as próteses parafusadas, independente do carregamento. A esplintagem foi 
favorável somente para as próteses parafusadas, não havendo influência sobre as próteses cimentadas. As próteses cimentadas sobre implantes cone Morse apresentam melhor comportamento biomecânico nos implantes/ componentes e tecido ósseo. A esplintagem foi efetiva somente nas próteses parafusadas sob carregamento obliquo.

\section{Acknowledgements}

This work was supported by The São Paulo State Research Foundation (FAPESP) in the form of a scholarship grant \#2014/02490-8.

\section{References}

1. Mangano $C$, laculli $F$, Piattelli A, Mangano F. Fixed restorations supported by Morse-taper connection implants: a retrospective clinical study with 10-20 years of follow-up. Clin Oral Implants Res 2015;26:1229-1236.

2. Alves DC, Carvalho PS, Martinez EF. In vitro microbiological analysis of bacterial seal at the implant-abutment interface using two Morse taper implant models. Braz Dent J 2014;25:48-53.

3. Santiago JF Junior, Verri FR, Almeida DA, de Souza Batista VE, Lemos CA, Pellizzer EP. Finite element analysis on influence of implant surface treatments, connection and bone types. Mater Sci Eng C Mater Biol Appl 2016;63:292-300.

4. Clelland N, Chaudhry J, Rashid RG, McGlumphy E. Split-mouth comparison of splinted and non splinted prostheses on short implants: 3-year results. Int J Oral Maxillofac Implants. 2016;31:1135-1141.

5. Mendonca JA, Francischone CE, Senna PM, Matos de Oliveira $A E$, Sotto-Maior BS. A retrospective evaluation of the survival rates of splinted and non-splinted short dental implants in posterior partially edentulous jaws. J Periodontol 2014;85:787-794.

6. Lemos CA, Ferro-Alves ML, Okamoto R, Mendonca MR, Pellizzer EP. Short dental implants versus standard dental implants placed in the posterior jaws: A systematic review and meta-analysis. J Dent 2016; 47:8-17.

7. Lemos CA, de Souza Batista VE, Almeida DA, Santiago Junior JF, Verri FR, Pellizzer EP. Evaluation of cement-retained versus screw-retained implant-supported restorations for marginal bone loss: A systematic review and meta-analysis. J Prosthet Dent 2015;115:419-427.

8. Shadid R, Sadaqa N. A comparison between screw- and cementretained implant prostheses. A literature review. J Oral Implantol 2012;38:298-307.

9. de Moraes SL, Verri FR, Santiago JF Jr, Almeida DA, de Mello CC, Pellizzer EP. A 3-D finite element study of the influence of crown-implant ratio on stress distribution. Braz Dent J 2013;24:635-341.

10. Spazzin AO, Dos Santos MB, Sobrinho LC, Consani RL, Mesquita MF. Effects of horizontal misfit and bar framework material on the stress distribution of an overdenture-retaining bar system: a 3D finite element analysis. J Prosthodont 2011;20:517-522.

11. Sertgöz A. Finite element analysis study of the effect of superstructure material on stress distribution in an implant-supported fixed prosthesis. Int J Prosthodont. 1997;10:19-27.
12. Anusavice KJ, Hojjatie B. Stress distribution in metal-ceramic crowns with a facial porcelain margin. J Dent Res 1987;66:1493-1498.

13. Minatel L, Verri FR, Kudo GAH, Almeida DAF, de Souza Batista VE, Lemos CAA, et al.. Effect of different types of prosthetic platforms on stressdistribution in dental implant-supported prostheses. Mater Sci Eng C Mater Biol Appl 2017;71:35-42.

14. de Vasconcellos DK, Kojima AN, Mesquita AM, Bottino MA, Ozcan M. A microstrain comparison of passively fitting screw-retained and cemented titanium frameworks. J Prosthet Dent 2014;112:834-838.

15. Silva GC, Cornacchia TM, de Magalhaes CS, Bueno AC, Moreira AN. Biomechanical evaluation of screw- and cement-retained implantsupported prostheses: a nonlinear finite element analysis. J Prosthet Dent 2014;112:1479-1488.

16. Guichet $D L$, Caputo $A A$, Choi $H$, Sorensen JA. Passivity of fit and marginal opening in screw- or cement-retained implant fixed partial denture designs. Int J Oral Maxillofac Implants 2000;15:239-246.

17. Nissan J, Narobai D, Gross 0, Ghelfan 0, Chaushu G. Long-term outcome of cemented versus screw-retained implant-supported partial restorations. Int J Oral Maxillofac Implants 2011;26:1102-1107.

18. Camargos G de V, Sotto-Maior BS, Silva WJ, Lazari PC, Del Bel Cury AA. Prosthetic abutment influences bone biomechanical behavior of immediately loaded implants. Braz Oral Res 2016;30. pii: S180683242016000100901. doi: 10.1590/1807-3107BOR-2016.vol30.0065.

19. Yilmaz B, Seidt JD, McGlumphy EA, Clelland NL. Comparison of strains for splinted and nonsplinted screw-retained prostheses on short implants. Int J Oral Maxillofac Implants 2011;26:1176-1182.

20. Pellizzer EP, de Mello CC, Santiago Junior JF, de Souza Batista VE, de Faria Almeida DA, Verri FR. Analysis of the biomechanical behavior of short implants: The photo-elasticity method. Mater Sci Eng C Mater Biol Appl 2015;55:187-192.

21. Anitua $E$, Orive $G$. Short implants in maxillae and mandibles: a retrospective study with 1 to 8 years of follow-up. J Periodontol 2010;81:819-826.

22. Yilmaz B, Mess J, Seidt J, Clelland NL. Strain comparisons for splinted and non-splinted cement-retained implant crowns. Int J Prosthodont 2013;26:235-238.

23. Lindhe J, Meyle J. Peri-implant diseases: Consensus Report of the Sixth European Workshop on Periodontology. J Clin Periodontol 2008;35:282-285.

24. Goiato MC, Torcato LB, Dos Santos DM, Moreno A, Antenucci RM, de Carvalho Dekon SF. Quality of life and satisfaction of patients wearing implant-supported fixed partial denture: a cross-sectional survey of patients from Aracatuba city, Brazil. Clin Oral Implants Res 2015;26:701-708.

25. Papavasiliou G, Kamposiora P, Bayne SC, Felton DA. Three-dimensional finite element analysis of stress-distribution around single tooth implants as a function of bony support, prosthesis type, and loading during function. J Prosthet Dent 1996;76:633-640.

Received January 11, 2017 Accepted September 11, 2017 